\title{
Perceptions of the role of pharmacy assistants in providing patient counselling in community pharmacies in Indonesia
}

\section{Percepcja roli asystentów farmaceutycznych w prowadzeniu poradnictwa dla pacjentów $w$ aptekach $w$ społecznościach lokalnych $w$ Indonezji}

\author{
I Gusti Ayu Rai Widowati¹, Dyah Pradnyaparamita-Duarsa², Pande Putu-Januraga ${ }^{2,3}$ \\ ${ }^{1}$ Doctoral Program, Faculty of Medicine, Udayana University, Bali, Indonesia \\ 2Department of Public Health and Preventive Medicine, Faculty of Medicine, Udayana University, Bali, Indonesia \\ ${ }^{3}$ Centre of Public Health Innovation, Faculty of Medicine, Udayana University, Bali, Indonesia
}

Medical Studies/Studia Medyczne 2021; 37 (2): 117-124

DOI: https://doi.org/10.5114/ms.2021.107455

Key words: competency, patient counselling, pharmacy assistant, community pharmacy, Indonesia.

Słowa kluczowe: kompetencja, poradnictwo dla pacjentów, asystent farmaceutyczny, apteka w społeczności lokalnej, Indonezja.

\begin{abstract}
Introduction: Patient counselling is a part of pharmaceutical services, where there is interaction between pharmacy workers with patients to provide drug information to improve patient safety. Pharmacy assistants are on the frontline of community pharmaceutical services in Indonesia, but regulations do not give them the authority to provide patient counselling.

Aim of the research: This study explored pharmacy workers' perceptions about the role of pharmacy assistants to provide patient counselling within the community.

Material and methods: This was an exploratory qualitative study with 17 participants, comprising 9 pharmacists and 8 pharmacy assistants recruited through purposive sampling. Data were collected from May to June 2020. Semi-structured interviews were conducted to collect qualitative data on pharmacy workers' perceptions regarding patient counselling provided by pharmacy assistants. Data analysis was performed thematically.

Results: This is the first study to date to explore the perceptions of pharmacy workers regarding the role of patient counselling by pharmacy assistants. Pharmacy workers believed that modified patient counselling could be conducted by pharmacy assistants, taking into account the following 6 aspects: the use of the term counselling, content and context, duration of interactions with patients, competency of service providers, infrastructure, and training needs.

Conclusions: To be accepted by stakeholders, patient counselling provided by pharmacy assistants should be modified to consider aspects of competence and supportive infrastructure.

\section{Streszczenie}

Wprowadzenie: $\mathrm{W}$ ramach poradnictwa dla pacjentów, które stanowi część usług farmaceutycznych, dochodzi do interakcji pomiędzy pracownikami apteki a pacjentami w celu przekazania informacji o lekach dla poprawy bezpieczeństwa pacjentów. Asystenci farmaceutyczni stoją na pierwszej linii usług farmaceutycznych w społeczności lokalnej w Indonezji, jednak przepisy nie dają im uprawnień do udzielania porad pacjentom.

Cel pracy: Niniejsze badanie dotyczyło postrzegania przez pracowników aptek roli asystentów farmaceutycznych w udzielaniu porad pacjentom $\mathrm{w}$ ramach społeczności lokalnej.

Materiał i metody: Było to jakościowe badanie eksploracyjne obejmujące 17 uczestników, w tym 9 farmaceutów i 8 asystentów farmaceutycznych, których rekrutowano w drodze doboru celowego. Dane gromadzono od maja do czerwca $2020 \mathrm{r}$. W celu zebrania danych jakościowych na temat percepcji pracowników aptek pod kątem porad udzielanych przez asystentów farmaceutycznych przeprowadzono badanie metodą wywiadu częściowo ustrukturyzowanego. Analiza danych została przeprowadzona w sposób tematyczny.

Wyniki: Jest to pierwsze badanie poświęcone postrzeganiu przez pracowników aptek roli, jaką w poradnictwie dla pacjentów odgrywają asystenci farmaceutyczni. Pracownicy aptek uważali, że zmodyfikowane poradnictwo dla pacjentów może być prowadzone przez asystentów farmaceutycznych, uwzględniając następujące aspekty: użycie terminu poradnictwo, treść i kontekst, czas trwania interakcji z pacjentem, kompetencje osób świadczących usługi, infrastrukturę i potrzeby szkoleniowe. Wnioski: Aby poradnictwo dla pacjentów świadczone przez asystentów farmaceutycznych zyskało akceptację zainteresowanych stron, powinno zostać zmodyfikowane i uwzględniać aspekty kompetencji i infrastruktury wspierającej.
\end{abstract}




\section{Introduction}

The demand for quality healthcare services, including pharmaceutical services, continues to increase in Indonesia. There has been a shift in the purpose of pharmaceutical services, from medication management to providing pharmaceutical care, including information services to support proper and rational medication use, monitoring medication usage to achieve the final goal of patient safety, and detecting possible medication errors, which are preventable errors that can potentially endanger patients. Medication errors can occur at the stages of prescribing, transcribing, dispensing, and administering [1].

Indonesia is a developing country with a rapidly growing pharmaceutical industry, including community pharmacies. According to Indonesian Pharmacy Recapitulation data from the Ministry of Health of the Republic of Indonesia, there were 24,874 pharmacies throughout Indonesia as of 2018. For example, the province of Bali has 674 pharmacies, with approximately 1000 pharmacists and 1600 pharmacy assistants registered with professional organizations. Pharmacy assistants support pharmacists in conducting their work and dominate the workforce at various levels of pharmaceutical services in Indonesia.

In line with the efforts to improve the quality of pharmaceutical services, pharmacists in Indonesia have become involved in health promotion and public health practices with the introduction of the Smart Community Drug Use Program launched by the Ministry of Health of the Republic of Indonesia on 13 November 2015. Pharmacy counselling and educational services provided by pharmacists when dispensing drugs to patients have been shown to increase medication adherence [2-4]. Furthermore, appropriate and consistent pharmacy counselling services are expected to upgrade the roles and enhance the reputation of pharmaceutical personnel in the wider community, and they can improve public health overall.

In terms of how their time is spent during working hours, pharmacists should ideally prioritize pharmaceutical care; however, they often experience a role conflict between being an entrepreneur who manages a pharmacy and providing pharmaceutical services to patients [5]. Nevertheless, although they may be preoccupied with managerial tasks, a pharmacist's physical presence and direct control over the provision of pharmacy counselling is still very important. This is firmly embedded in the culture of public pharmacies, possibly because it has so far been a legal requirement [6]. Under current conditions, pharmacists could work effectively by delegating some roles to pharmacy assistants, including patient counselling, thus allowing for the provision of pharmaceutical services to be optimized.

It is a common practice in developing countries with a limited number of available pharmacists to provide continuous pharmaceutical services during operating hours. Pharmacy assistants' role in developing countries is often to ensure the availability of basic services [7], unlike in high-income countries, where pharmaceutical support staff work more closely with pharmacists to deliver a variety of more complex pharmaceutical services [8]. However, how pharmacy workers' perceptions relate to the delegation of patient counselling to pharmacy assistants as well as the need for increased competence and training remain unknown.

\section{Aim of the research}

Thus, this study aimed to explore the perceptions of pharmacy workers regarding pharmacy assistants' role in safely and responsibly conducting patient counselling and strategies that can be developed to enhance the role of pharmacy assistants in pharmaceutical counselling services. This is expected to have a positive effect on professional and responsible pharmacy services provided at community pharmacies, where patient counselling aims to inform the patient's understanding of the therapy they are undergoing, increase adherence, and motivate patients to take part in their health.

\section{Material and methods}

This was an exploratory qualitative study conducted using an in-depth interview approach with pharmacists and pharmacy assistants. Seventeen participants, comprising 9 pharmacists and 8 pharmacy assistants, were recruited from various community pharmacies in the province of Bali, using purposive sampling. The inclusion criterion for the participants was pharmacists who represented their pharmacy (i.e. owners or pharmacy managers only), to obtain diverse perspectives. Pharmacy assistants selected for interviews included those who had already met their degree requirements and were working full-time as well as those who were still students (i.e. pursuing their diploma while working part-time). All participants were also administrators or active members in their respective professional organizations, because they were considered to represent general perspectives on the requirements necessary for pharmaceutical practice.

Data were collected from May to June 2020. Appointments were scheduled via a WhatsApp text before the interview. Long-distance interviews with individual respondents were conducted using WhatsApp voice calls that lasted at least $45 \mathrm{~min}$. The interviews explored the respondents' views on patient counselling conducted by pharmacy assistants and the factors that would be necessary for pharmacy assistants to provide patient counselling. Before conducting the interview, consent was obtained from each participant via telephone. Each interview was recorded and transcribed verbatim.

Coding was performed simultaneously with data collection; each interview was coded as soon as the 
transcript was available, without waiting for all interviews to be completed. This was to determine when data saturation had been reached, so that participant recruitment could be stopped. Thematic analysis using an inductive approach was used in the present study, in which data were examined through a process that runs from facts. This type of data analysis focuses on a particular aspect of the case. Through this type of analysis, detailed case descriptions emerge in which the researcher focuses on some of the main problems (or analysis of themes); the aim is not to generalize outside the given case. At the final interpretive stage, the researcher reports the meaning of the case, about the case problem, and the unusual situation (in this case, if patient counselling is delegated to pharmacy assistants).

The purpose of using an inductive approach was to summarize raw textual data into a short format, thereby building a clear relationship between the research objectives and a summary of the findings derived from raw data, as well as to develop a framework. This inductive approach further provided a set of procedures that are generally easy to use, systematic, and can produce valid findings [9]. The internal validity of the data was ensured through triangulation by considering information from various participant perspectives.
This study was approved by the Ethics Committee of the Faculty of Medicine, Udayana University and Sanglah General Hospital, Denpasar, on 15 April 2020 (approval number 978/UN14.2.2.VII.14/LT/2020).

\section{Results}

\section{Participant characteristics}

The participants comprised 17 pharmacy workers, including 9 community pharmacists who held various positions (i.e. pharmacy owner, clinic manager, pharmacy manager, pharmacy lecturer, and Civil State Apparatus) and 8 pharmacy assistants, including 5 who worked full-time and 3 who worked parttime while continuing their education. As shown in Table 1, participants' ages ranged from 22 to 63 years, and they had 2-35 years of experience of working at a community pharmacy.

The analysis of the in-depth interview resulted in 6 main themes related to pharmacy workers' perceptions about pharmacy assistants' authority to counsel patients in community pharmacies: use of the term counselling, content and context, duration of interactions with patients, competency of service providers, infrastructure, facilities, and training needs. Table 2 presents a summary of the themes and sub-themes identified from the interviews.

Table 1. Participant characteristics

\begin{tabular}{|lcccc|}
\hline Participant code & Age [years] & Gender & Experience [years] & Position \\
P-1 & 47 & Female & 22 & Owner, pharmacy manager \\
P-2 & 48 & Female & 23 & Clinic and pharmacy manager \\
P-3 & 63 & Male & 35 & Owner, pharmacy manager \\
P-4 & 47 & Female & 22 & Owner, pharmacy manager \\
P-5 & 38 & Male & 13 & Owner, pharmacy manager \\
P-6 & 47 & Female & 22 & Owner, pharmacy manager \\
P-7 & 46 & Female & 21 & Owner, pharmacy manager, civil state \\
P-8 & 36 & Male & 11 & apparatus \\
P-9 & 50 & Female & 25 & Pharmacy manager, civil state apparatus \\
PA-1 & 40 & Female & 20 & Pharmacy Lecturer \\
PA-2 & 30 & Female & 10 & Full-time \\
PA-3 & 53 & Male & 33 & Full-time \\
PA-4 & 46 & Male & 26 & Full-time \\
PA-5 & 22 & Female & 3 & Full-time \\
PT-1 & 23 & Male & 3 & Part-time \\
PT-2 & 22 & Female & 2 & Part-time \\
PT-3 & 22 & Male & 2 & Part-time \\
\hline P-phalme & & 25 & \\
\hline
\end{tabular}

P - pharmacist, PA - pharmacy assistant who has received their diploma, PT - pharmacy assistant continuing their education. 
Table 2. Summary of themes and sub-themes

\begin{tabular}{|c|c|}
\hline Theme & Sub-theme \\
\hline $\begin{array}{l}\text { Use of the term } \\
\text { counselling }\end{array}$ & $\begin{array}{l}\text { The use of the term counselling to mean client-centred assistance provided by an expert } \\
\text { (counsellor) to individuals who are experiencing some type of problem (counselee) }\end{array}$ \\
\hline Context and content & $\begin{array}{l}\text { The idea includes inter-professional relationships, the role of pharmacy assistants, and the } \\
\text { ability to conduct patient counselling. } \\
\text { A new strategy was created using a new model (new guidelines), which was modified from } \\
\text { the previous guidelines (which were never implemented) }\end{array}$ \\
\hline $\begin{array}{l}\text { Duration of } \\
\text { interactions } \\
\text { with patients }\end{array}$ & $\begin{array}{l}\text { Poor-quality interactions between pharmacy workers and patients, complex workflow } \\
\text { especially during rush hour, counselling duration must be adjusted so as not to result in long } \\
\text { waiting times for patients }\end{array}$ \\
\hline $\begin{array}{l}\text { Competency of } \\
\text { service providers }\end{array}$ & $\begin{array}{l}\text { Pharmacy assistants' lack of competence, self-confidence, or communication skills; providing } \\
\text { information about treatment that is unclear, indicating that competence should be increased }\end{array}$ \\
\hline Infrastructure & Private area to provide patient counselling \\
\hline Training needs & Adequate training to meet pharmacy assistants' needs in providing patient counselling \\
\hline
\end{tabular}

\section{Theme 1: use of the term counselling}

It is important to capture the perceptions and opinions of pharmaceutical workers regarding patient counselling services because the public often lacks optimal communication services, information, and drug education. Most of the pharmaceutical workers interviewed in this study supported the professional implementation of patient counselling. Regulations were mentioned as the main driver for pharmaceutical workers to provide drug information services to patients. Most participants thought that patient counselling, as traditionally defined, is a part of the pharmaceutical profession; however, the pharmacy assistants' professional qualification was considered inadequate for counselling. This emerged as the main reason why the participants expressed that the use of the term "counselling" should be reviewed for counselling conducted by pharmacy assistants, and a more fitting term, such as "communication", should be used instead.

"...patient counselling is delivered to improve the quality of the pharmacy practice. If delivered by pharmacy assistants, it is called drug information ... just like that [meaning the information delivered quickly]." (P-3)

"The thing about counselling is...I think it should be delivered by a consultant [meaning a pharmacist, not a pharmacy assistant]." (P-7)

"Counselling means to consult about a problem that needs exploration... counselling is related to the profession. So, if we want counselling by pharmacy assistants, we should call it something else, such as communication, information, education, etc., so that there is no conflict within the profession." (P-8)

"Counselling should be delivered by pharmacists; if delivered by assistant, it is drug information..." (PA-1)

\section{Theme 2: context and content}

What information, and to what extent, can be provided to patients by pharmacy assistants came up as an issue of concern in the interviews. In drug information services, participants reported to set limits on pharmacy assistants according to their capabilities.

"As far as they know, like the indication [the use] of the medicine, the frequency of taking the medicine, and how to take the medicine [before/after meals]... if the prescription is polypharmacy, the pharmacist should explain the complications." (P-1)

"Usually, if there is a new drug or...conditions that are in season, for example there is now COVID-19 emerging, at least the pharmacy assistant should know what answer to give, because patients ask a lot [of questions]." (P-2)

"...the technical ones...for example, how to use, how to store, and then how to dispose of [medications]..." (P-6)

"Since [working towards my diploma], we have been told there are limits [to the information] that we may give." (PT-2)

Most participants reported that they did not play an active role in monitoring the effectiveness of therapy, side effects, or drug safety. As such, gaps were identified in drug education practice that need to be addressed in the future to meet professional practice guidelines. Furthermore, participants identified a need to develop strategies to improve practices related to verbal counselling, as well as written drug information, and to increase consumer involvement in the process.

"When the patient goes [from the pharmacy], the patient issue/problem/adherence is never followed up on again...” (PA-1)

"So far, there have been no complaints after [patients are] given medication. If patients do not ask again, it means there is no problem." (PA-2) 


\section{Theme 3: duration of interactions with patients}

Social interaction between pharmacists and patients is a form of communication that can be used to bridge the gap and build a short relationship with the intention of increasing trust by both parties (i.e. message giver and receiver); however, patients are sometimes passive, making these interactions unbalanced. Most participants reported that interactions with patients were typically rushed and not systematic, especially during busy times.

"If it's a simple prescription, it's 3-5 minutes...with counselling, it can be up to 15 minutes per patient. If it is simple, at the most this drug is taken all the time [refill prescription], it should not take more than 5 minutes." (P-1)

"[Patient interactions take] five to ten minutes, depending on questions raised by customers or patients." (P-6)

"If the patient said yes, yes [in hurry]... [the interaction takes] at least 1 minute.” (PA-4)

There are opportunities for pharmacists to focus more on direct interaction with patients, such as becoming better known by their profession as a health service provider. However, participants reported their workflow often prevents them from fulfilling this service. Reported obstacles related to pharmaceutical workflow include lack of time to engage with patients, difficulty documenting services, inadequate staff support, inadequate facilities or resources, and lack of top-level management support.

"Counselling cannot be done 24 hours [as long as the pharmacy is open]. It is recommended that large/ busy pharmacies have a companion pharmacist who works 3-4 hours [for counselling]." (P-6)

"When we are busy, we work fast, as consideration for patients who are queuing up.” (PA-3)

Long waiting times are likely to reduce productivity due to the loss of work time. Although participants recognized that the pharmacies where they worked had adequate waiting rooms in accordance with their respective conditions and business capacities (seen from the number of patient visits or pharmacy revenue), there were still concerns about queues resulting from the provision of time-consuming additional services.

\section{Theme 4: competency of service providers}

Pharmacy assistants' competency standards indicate that they should be able to convey information to the public according to the ethics of the pharmaceutical profession, provide information on pharmaceutical preparations for patient services, and deliver public education on the safe use of drugs. From the pharmacist's point of view, participants acknowledged that, when implementing pharmaceutical services, pharmacy assistants could be very helpful and support them in providing smooth service to the community.
"Actually, the one more in contact with the patients is the pharmacy assistant, and in my opinion pharmacy assistants are our partners, which means they [pharmacy assistants] can replace us in providing drug information services to patients. Although it [pharmacy assistants' knowledge] is not as detailed as ours [pharmacists'], but I believe that pharmacy assistants also have the ability and knowledge." (P-2)

"If the pharmacy assistant has experience, they [pharmacy assistants] are already flexible in giving modified counselling." (P-4)

"The pharmacy assistant is [in a] degree [program] right now; the intention is to provide modified counselling, and as pharmacy assistants are pursuing the required education, it meets the requirements, meaning that they are capable [of providing drug information to patients]." (P-7)

In contrast, the pharmacy assistant participants showed self-awareness of their limitations, which was related to their perceived self-confidence. Pharmacy assistants' perceptions of traditional pharmaceutical culture and previous experiences at other pharmacies influenced their perceptions regarding the idea of taking on new roles. Even those pharmacy assistants who supported the idea of pharmaceutical counselling services expressed initial reluctance to take on new responsibilities, due to an awareness of professional ranking. However, experienced pharmacy assistants expressed confidence in their ability to provide good education to patients.

"I said the item [medicine] was out of stock/sold out, like that. Just a simple answer [that did not] violate the rules." (PA-2)

"As much as possible, I give advice according to my experience." (PA-3)

Pharmacist participants who were also pharmacy owners and managers considered that the general attitude of pharmacy assistants is very important. The majority of pharmacist participants agreed that certified pharmacy assistants are more valuable in the workplace.

"...It is very important that the pharmacy assistant has good attitude and communication skills, in addition to basic competency." (P-6)

"...It could be even better, in my opinion...it would be beneficial on the one hand if pharmacy assistant received the certification ...huh...certificate of accompanying diploma, it's very beneficial." (P-9)

Pharmacist participants who were also lecturers in pharmacy diploma courses revealed that pharmacy assistants' competencies must meet the minimum standards when carrying out their duties as pharmaceutical staff.

"Modules [have been] created to assist and bridge the absence of pharmacists and their obligation to provide modified counselling assisted by pharmacy assistants. So instead of not providing authority, the 
curriculum will refer to the APDFI [Association of Indonesian Pharmacy Diploma Education] [for] the content of competencies expected of graduates." (P-9)

\section{Theme 5: infrastructure}

Regarding the infrastructure at their workplaces, all participants reported that the area for reception and delivery of prescriptions was in the front of the pharmacy, beside adequate waiting rooms to speed up the service process; however, not all pharmacies have private patient counselling rooms to share confidential information and education.

"There is a private space, but so far, we [have given] patients counselling at the pharmacist's special counter [table and chair], because these cases are not confidential cases." (P-1) "If it's confidential, for example in the case of venereal disease, I take a doctor's room that isn't currently in [use]." (P-3)

"In the pharmacy, I happen to stand by as the pharmacist...over the telephone or over WhatsApp; there are some regular/loyal customers who are usually in touch with me on WhatsApp." (P-4) PA-4)

"Just in front at the time of submission." (P-6, PA-3,

"Drug information is carried out at the front counter [cashier area] when the medicine is given to the patient.” (P-6, PA-3, PA-4)

\section{Theme 6: training needs}

For pharmacy assistants to take on an additional role, more formal trainings, educational programs, and individual capacity building are required. The benefits of improving drug information services for patients and can help inspire pharmacy assistants to pursue this additional role. Most participants acknowledged that more pharmacy assistant training is needed to improve their abilities and help move patient counselling services in a better direction.

"If there is a modified counselling training that a pharmacy assistant can do, I totally agree, this will be very helpful in providing drug information to patients..." (P-2)

"In addition to improving the knowledge and skills of pharmacy assistants, [which] is very good, later, all pharmacy owners and pharmacist managers should assign their pharmacy assistants to obtain certification [provided by a professional organization, certifying that the person is capable of doing a specific job or task]; that's the future goal." (P-3)

"Pharmacy assistants need additional skills...like communication skills." (P-4)

"Training can be conducted virtually, now [it is] easy to do using Zoom." (P-6)

"Maybe [it would be] easier if the training had more role play, so it could be directly practiced in the field." (PT-3)

\section{Discussion}

Pharmacy assistants play an important support role in providing clinical pharmacy services in highperformance community pharmacies. Clinical support responsibilities include reviewing prescriptions, dispensing medications, providing drug information services, providing home pharmacy care, and monitoring drug therapy and medication side effects [1]. The present study found that the key informants' overall perceptions regarding pharmacy assistants' authority to provide modified pharmaceutical counselling, in relation to their work capabilities and quality, were positive. This finding is in line with previous literature offering support for pharmacy assistants' additional roles in order to meet patients' needs and provide pharmacists with the opportunity to engage in other clinical services [9].

The term "patient counselling" is defined as a series of direct interactions between counsellors (pharmaceutical personnel) and counselees (patients) to assist in changing the latter's attitudes and medical behaviour. Counselling conducted by pharmacists is a component of pharmaceutical care, and a clinical pharmacy service is meant to improve patient knowledge and understanding and solve patients' problems related to medication use [10]. Although the current data is fraught with intense discussion regarding the use of the term "counselling" when it is conducted by pharmacy assistants, there is a clue so that information about the drug to patients can be optimally carried out.

Additionally, the results of this study indicate that the interactions between pharmaceutical personnel and patients are generally short in duration. One way to overcome gaps in information due to lack of interaction with patients is to provide information in writing. This is supported by research on the accuracy and relevance of written communication, which is essential for the use of appropriate prescription drugs [11]. A previous study highlighted the importance of providing written information to patients regarding the drugs prescribed for their treatment [12], and special one-page leaflets can enhance the information process for consumers by reducing their cognitive load [13]. A systematic review of written information from patients' perspectives showed that patients value written information and use it for decision-making, thus further improving their medication adherence [14].

Regarding the influence of concerns about patients' waiting time leading to minimal interactions between patients and pharmacy workers, some previous studies have also shown that long waiting times can increase patients' physical and emotional stress, thereby negatively impacting their health, and reducing the efficacy of the treatment they eventually receive. Moreover, waiting time also indirectly contributes to decreased productivity of pharmacy workers 
due to loss of work time. There is a strong correlation between involvement in medication therapy management services and satisfaction with pharmaceutical services $[15,16]$. The main elements related to pharmacy waiting time include how to receive prescriptions, workflow, availability of pharmaceutical staff, and interactions with pharmaceutical staff [16]. A literature review reported that effective techniques have been successfully applied to reduce pharmacy waiting times, such as queuing theory, tele-pharmacy, modelling, and system simulation to identify the potential processes behind drug dispensing and potential problems associated with increased waiting times [17].

Implementing drug information service standards in pharmacies must be supported by available pharmaceutical resources oriented toward patient safety. Pharmaceutical resources include human resources, facilities, and infrastructure. Pharmacy facilities must be easily accessible to the community, to help guarantee the quality of pharmaceutical preparations and the smooth practice of pharmaceutical services. Space requirements should be regulated to obtain adequate lighting and air circulation [1]. In terms of diversity in community pharmacy appearance, researchers have argued that providing space and facilities and allocating time for pharmaceutical counselling will offer broad benefits. Access to community pharmacists offered by pharmacy chains, involvement in the medication use process, and the ability to observe self-care behaviours related to over-the-counter medicines and supplements provide opportunities for community pharmacy workers to develop insights into medication use issues from other perspectives [18].

To improve pharmaceutical services provided in community pharmacies, training for pharmacy assistants should aim to increase their confidence in providing patient counselling. A trained and confident pharmacy assistant can communicate proactively to educate patients, thus having a positive impact on patients' knowledge, attitude, and medication adherence. Although trained pharmacists are essential to the success of the pharmaceutical business, to date, training has only been prioritized for pharmacists. Additionally, it has been shown that pharmacy owners do not prioritize training or credential requirements for pharmacy assistants [19]. The results of this study underscore the scope of involving pharmacy assistants in the process of imparting essential knowledge to the patients and provide important lessons for the involvement of pharmacy assistants in the future. However, pharmacy assistants may need more training and ongoing development (e.g. communication skills, handling complaints, self-performance, etc.) when starting a new role in patient counselling services. Nevertheless, as the involvement of pharmacy assistants potentially increases patient satisfaction, opportunities for them to be more actively involved in playing their new role would also increase. Furthermore, pharmacy assistants need to be provided with role clarity, so that service standards can be designed to meet not only current practice needs but also future needs. As pharmacists and assistant pharmacists in hospitals have more advanced capabilities and skills, community pharmacies can adopt methods to support a model that allows pharmacists to take on an expanded clinical role [20].

The new direction in certification is due to the rapidly changing pharmaceutical landscape, which revolves around new and expanded clinical pharmacy services. This also reveals that there are potentially new opportunities and needs associated with pharmacy assistant certification [19]. In regulating pharmacy assistants, there is an implicit understanding that professional ethos will grow, and standards of practice, competency expectations, and requirements for continuing professional development will improve [21].

Pharmacy workers are health workers who have the responsibility to help people in their own treatment based on their knowledge of pharmaceutical science. Appropriate and consistent pharmaceutical services will increase the role and reputation of pharmacy workers in the wider community as well as improving the health status of the community. Further research is needed to continue to evaluate the relationship between providing pharmaceutical counselling and pharmacy assistant involvement, as well as the barriers to involving pharmacy assistants in this service. Also, with the limited numbers and scope of interviews in this study, future studies should consider exploring determinants of the perception of the role of the pharmacy assistant in pharmaceutical care counselling. To our knowledge, this is the first study to date to explore the perceptions of pharmacy workers regarding the role of patient counselling by pharmacy assistants. The results of this study provide important insights for guiding future directions for counselling services by pharmacy assistants to be accepted by the various stakeholders. The authority to provide pharmaceutical counselling by pharmacy assistants should be modified by paying attention to aspects of competence, such as scope and responsibility, and supporting infrastructure, such as creating more areas where private counselling can be provided.

A limitation of this study is that the interviews were only conducted with pharmacy workers in community pharmacy services, and data from other perspectives (e.g. patients, non-pharmacist owners) were not captured; therefore, these findings may not represent the overall perspective in Indonesia. Thus, further research is needed to explore the perceptions of other relevant groups, such as those who provide pharmaceutical services at primary healthcare facilities (e.g. health centres and inpatient clinics). 


\section{Conclusions}

Pharmacy assistants support pharmacists in various aspects of the job, including providing modified patient counselling to improve services offered at community pharmacies. The pharmacy workers in the present study were of the opinion that patient counselling could be provided by pharmacy assistants, provided that attention is paid to the use of the term counselling, content and context of counselling, duration of interactions with patients, competency of service providers, infrastructure, and the training needs of pharmacy assistants.

Furthermore, it is clear that if changes are made to delegate patient counselling to pharmacy assistants, extensive procedural work would be required to provide guidelines and standard operating procedures for periods in which pharmacists are not available. Thus, it is necessary to ensure that pharmacy assistants are adequately trained, have appropriate qualifications for this role, and that their professional responsibilities and level of accountability are clarified.

\section{Acknowledgments}

The researchers would like to thank all the participants who have supported this research.

\section{Conflict of interest}

The authors declare no conflict of interest.

\section{References}

1. Menkes RI. Peraturan Menteri Kesehatan Republik Indonesia Nomor 73. Jakarta; 2016.

2. Widowati IGAR, Wirawan IMA, Nopiyani NMS, Sari KAK. Pharmacist counselling intervention to improve patient antibiotic compliance. Public Health Prev Med Arch 2019; 6: 128.

3. Pringle JL, Boyer A, Conklin MH, McCullough JW, Aldridge A. The Pennsylvania Project: pharmacist intervention improved medication adherence and reduced health care costs. Health Affairs 2014; 33: 1444-1452.

4. West LM, Cordina M. Educational intervention to enhance adherence to short-term use of antibiotics. Res Soc Admin Pharm 2019; 15: 193-201.

5. Hermansyah A, Sukorini AI, Setiawan CD, Priyandani Y. The conflicts between professional and non-professional work of community pharmacists in Indonesia. Pharm Pract 2012; 10: 33-39.

6. Bradley F, Schafheutle EI, Willis SC, Noyce PR. Changes to supervision in community pharmacy: pharmacist and pharmacy support staff views. Health Soc Care Commun 2013; 21: 644-654.

7. Brown A, Cometto G, Cumbi A, de Pinho H, Kamwendo F, Lehmann U, McCourt W, McPake B, Pariyo G, Sanders D. Mid-level health providers: a promising resource. Rev Peru Med Exp Salud Publica 2011; 28: 308-315.

8. Zellmer WA. The future of health-system pharmacy: opportunities and challenges in practice model change. Ann Pharmacother 2012; 46: 41-45.
9. Mattingly AN, Mattingly TJ. Advancing the role of the pharmacy technician: a systematic review. J Am Pharm Assoc 2018; 58: 94-108.

10. Naughton CA. Patient-centered communication. Pharmacy 2018; 6: 18.

11. Bernardini C, Ambrogi V, Fardella G, Perioli L, Grandolini G. How to improve the readability of the patient package leaflet: a survey on the use of colour, print size and layout. Pharmacol Res 2001; 43: 437-443.

12. Liu F, Abdul-Hussain S, Mahboob S, Rai V, Kostrzewski A. How useful are medication patient information leaflets to older adults? A content, readability and layout analysis. Int J Clin Pharm 2014; 36: 827-834.

13. Patel HK, Bapat SS, Bhansali AH, Sansgiry SS. Development of prescription drug information leaflets: Impact of cognitive effort and patient involvement on prescription medication onformation processing. Ther Innov Regul Sci 2018; 52: 118-129.

14. Shrank W, Avorn J, Rolon C, Shekelle P. Effect of content and format of prescription drug labels on readability, understanding, and medication use: a systematic review. Ann Pharmacother 2007; 41: 783-801.

15. Kallen MA, Terrell JA, Lewis-Patterson P, Hwang JP. Improving wait time for chemotherapy in an outpatient clinic at a comprehensive cancer center. J Oncol Pract 2012; 8: e1-e7.

16. Bahadori M, Mohammadnejhad SM, Ravangard R, Teymourzadeh E. Using queuing theory and simulation model to optimize hospital pharmacy performance. Iran Red Crescent Med J 2014; 16: e16807.

17. Sandelands E. Reducing pharmacy patient waiting time. Int J Health Care Qual Assur 2018; 7: 1-40.

18. Schommer JC, Maine LL, Ellis WM, Douglas Ried Dean L. Establishing Pharmacist Practice-Based Research Networks. APhA Foundation White Paper 2010.

19. Renfro CP, Wheeler JS, McDonough SLK, Wang J, Hohmeier KC. Exploring employer perceptions of pharmacy technician certification in the community pharmacy setting. Res Social Adm Pharm 2020; 16: 1215-1219.

20. Schafheutle EI, Jee SD, Willis SC. Fitness for purpose of pharmacy technician education and training: the case of Great Britain. Res Social Adm Pharm 2017; 13: 88-97.

21. Jetha M, Walji A, Gregory P, Abdulla D, Austin Z. Pharmacist - pharmacy technician intraprofessional collaboration and workplace integration: implications for educators. Pharmacy 2020; 8: 95.

\section{Address for correspondence:}

\section{Gusti Ayu Rai Widowati}

Doctoral Program

Faculty of Medicine

Udayana University

Bali, Indonesia

E-mail: gekrai@angligan.com 